\title{
Political Deadlock and Judicial De-Integration in the Single European Pharmaceutical Market
}

\author{
Peter Kotzian* \\ Technical University of Darmstadt, D-64283 Darmstadt, Germany
}

\begin{abstract}
European integration in the pharmaceutical market is characterized by unequal progress. Achieved tradability and retained national price controls resulted in parallel trade for pharmaceuticals. The paper explains the processes and the outcomes of a long term negotiation process among member states, EU Commission and the pharmaceutical industry. The paper derives the constellation of preferences, analyzes the negotiation situation and explains the persisting deadlock, in which persisting divergence of preferences among the actors involved obstructed any political solution.

As a clear case in point of Tsebelis' theoretical argument, this disagreement enabled the European Court of Justice to act as a stand-in policy maker. With its judgments, the court is setting a de-integration solution, which is tolerated by all political actors, albeit they could not agree on this policy in the negotiations. The solution set is likely to be stable, because there is no consensus to revoke it.
\end{abstract}

\section{INTRODUCTION: PHARMACEUTICALS IN EURO- PE BETWEEN SINGLE MARKET ELEMENTS AND RETAINED NATIONAL CONTROL}

Health care, in particular organizational questions of financing and provision, is excluded from positive European integration. Existing integration in health care is equally a product of intended political integration efforts like harmonization of product standards for pharmaceuticals or the creation of the EMEA, as it is a product of a spill-overeffect: contradictions among principles like that of free trade vs. national competence for the organization of health care provision as laid down in the treaties create tensions due to the character of health as a service and a good. The ECJ is a driving actor in this 'integration by spill-over', the most striking examples being its judgments in the cases concerning the free movement of patients purchasing medical services abroad. Albeit there were no immediate consequences of the judgements for pharmaceuticals, the ECJ's judgments stirred substantial unrest (Kanavos 2000, Mossialos \& Palm 2003 and Martinsen 2005). One reason for the increased activity in the domain of the single pharmaceutical market in the 1990s was the fear that a solution imposed by the ECJ could be worse than a negotiated political solution.

Europeanization in pharmaceuticals, i.e. harmonization and centralization, has gone very far in some issues but remained virtually absent in others. Integrated issues are for instance product safety and market authorization, culminating in the centralized market authorization procedure and the European Medicines Agency (EMEA) in $1995^{1}$. Trade in

*Address correspondence to this author at the Technical University of Darmstadt, D-64283 Darmstadt, Germany;

E-mail: kotzian@pg.tu-darmstadt.de

\footnotetext{
${ }^{1}$ See Commission (2003), Garattini \& Bertele (2004) and Hancher (2004), for the achieved Europeanization.
}

pharmaceuticals among national markets was greatly facilitated and is also legally endorsed by the European Court of Justice $(E C J)^{2}$. On the other hand, the reimbursement of pharmaceuticals by national health systems and price setting remained an explicit national competence. Despite some attempts, integration did not make any progress here (see Shechter 1998 and Hancher 2004). While the Commission views price regulation as a distortion of a functioning market (Permanand/Mossialos 2005, 701), the ECJ accepted national price regulations as a legitimate mean to stabilize health expenditure as long as they are applied nondiscriminatory ( see the de Peijper case, C-104/75; or C391/92, Greece vs. Commission).

National price regulation can be direct, e.g. by way of an authoritative price setting done by the government or a government agency. It can take the less explicit form of coupling domestic prices to prices granted in other countries, which have a reputation for a certain price setting (reference pricing). Prices can be regulated by negotiations, where a "appropriate profit" is an explicit and accepted criterion. Price regulation can also consist in deliberately abstaining from any regulation. Countries in Southern Europe are an example of the direct regulation, which are moreover setting the price at low levels, the UK is an example of the explicit negotiation approach, while Germany is an example of unregulated and high prices.

Whatever the form of the regulation, the resulting prices have distributive effects of substantial magnitude and are outcomes of a political process in which the government weights different interests and motives (see Attridge 2003, $123 \mathrm{pp}$ for national pricing modes and other instruments of cost containment for pharmaceutical expenditure). Studies on the price levels found, that the level is strongly affected by considerations of costs and benefits for the country (cf. Danzon \& Chao 2000).

\footnotetext{
${ }^{2}$ See Kon \& Schaeffer (1997: 140), Forrester (2000) and the de Peijper case, C-104/75
} 
Moreover, the relationship between the form of regulation and its implied outcome is an instrumental one: On the side of the government, regulations are by character an instrument, aiming predominantly either at subsidizing (and attracting) the industry or at controlling pharmaceutical expenditure. The price granted for a pharmaceutical is the price a government sees as appropriate, given its internal mix of motives. A government's preference with regard to the mode of national regulation are substantive, not institutional: forms of price regulations are primarily chosen for their effects on expenditure. There is however, comparable to other sectors of health policy, a strong preference for a national level solution excluding all transfers of competencies to the European level (Van der Mei/Waddington 1998).

The preferences of the industry in the issue of price regulation are equally substantive. It too has no preference for a certain form of regulation per se (national or European) but is primarily aiming at increasing the price level and thus the profit. The industry's influence in the decision process rests on economic factors, e.g. the threat of relocation. But independent of its present location it can also exert influence by not entering the market if the price granted is not acceptable, in which case patients have no or delayed access to new medicines (Danzon et al. 2005).

The source of price differences among European countries are thus not differences in productivity, in demand or in supply, but differences in regulation and political decisions by which the prices are set. The immediate result of national price regulations are price differentials among national markets. The available data on price differentials for medicines in different countries is rare (see data in Darbà \& Rovira (1998, 130), Danzon/Chao (2000a), Berndt (2002, 63), Danzon \& Furukawa (2003) and Danzon et al. 2005). For inpatent products manufactured by research-oriented enterprises which are the focus of this paper, direct price regulation is the most important source of price variation (see Darbá/Rovira 1998, 132, Kanavos 2000, 525, and Danzon \& Chao 2000a).

The paper will deliver an analysis of the current situation in the EU pharmaceutical market, with a focus on its implications for governments, citizens and pharmaceutical enterprises. Starting from a short description of the problematic consequences of parallel trade the paper describes the negotiation processes by which stakeholders tried to tackle the problem. Based on the description of the problem, the paper will show that the way to a political, negotiated solution was blocked. At the level of the preferences, there is a universal rejection among the member states to integrate price setting for pharmaceuticals, while the preferences for the level of the prices differ substantially. The Commission is struck between its wish to foster the European pharmaceutical competition, and its obligation to foster or at least retain, the integration and single market.

For such a situation, the theory proposed by Tsebelis (2002), predicts that the ECJ has substantial leeway to make a decision, because there is no consensus to hold it check and to replace its judgment by a political solution. This is basically what happened: Because the situation was not accessible for a political solution, it was changed by an apolitical actor, the ECJ. The situation is retained, because after all, it represents an acceptable improvement compared to the previous situation and there is no consensus to change it.

\section{PARALLEL TRADE}

The causes of parallel trade are both of legal and economic nature and a result of the unequal Europeanization: without the achieved integration, the legal possibility for trade in pharmaceuticals between member states would not exist. Without price differences created by retained national control over pricing, no economic incentive would exist. The following elaboration shall introduce the problem of parallel trade and prepare the derivation of the interests the actors hold in the negotiations on the issues involved.

In the case of parallel trade, or equivalently parallel or reimports, medicines are available in different member states at different prices. Produced by the same manufacturer they are sold in different countries at the price the government granted in this market. They are bought by parallel traders in countries where the prices are set at a lower level, and exported to countries where the price level is higher. Here they are fed into the distribution chain, parallel to the medicines supplied by the manufacturer' subsidiary.

The argument in favor of parallel trade is that it allows savings: lower prices paid by the wholesalers are passed on to the consumers (patients or the health system). The magnitude of these savings is debated. Usually parallel traded medicines are sold to distributors at a marginally lower price than the original supplied by the original producer in this market (see Darbà \& Rovira 1998: 134, and OECD 2001, 53), implying that potential savings are appropriated by the parallel traders (Commission 1998, 4). Parallel trade for inpatent products creates the situation of competition during a period for which the patent holder is granted a monopoly as a reward for his innovation. If parallel trade works perfect, all national markets are supplied with medicines bought by parallel traders in the country with the lowest price throughout the single market. In practice transaction costs - e.g. repackaging and transportation - make parallel trade attractive only if the price differentials exceeds a certain threshold and the market is of a sufficient size (Darbà \& Rovira 1998, 130 and Ganslandt \& Maskus 2004). According to the literature, subject to parallel trade are especially in-patent medicines, due to the more significant price differences (Burstall (1990, 69). This is also the segment, where a high price is most important for a research oriented pharmaceutical enterprise which is under pressure to recover the $R \& D$ expenses as quickly as possible.

National price controls and the resulting parallel trade affect all actors in the pharmaceutical market:

a) For the pharmaceutical industry, national price controls and parallel trade have several effects: First, there is a direct financial loss arising from regulation, understood as the difference between the price the enterprise would like to charge and the price it obtains under the existing regulation. Second, price regulation has two indirect effects: price regulations have spill-over effects to other markets, e.g. where reference price systems are in use. If a country sets the price at a low level, prices in countries referring to it will also set lower prices. The difference in the price levels causes losses due to parallel trade. These losses arise to the degree that pharmaceuticals offered by the 
original producer in a country at a certain (higher) price are substituted by imported ones, bought in a country where the original producer receives a lower price. These losses in turn have several long term effects, like a diminished capability and motivation for innovations and $\mathrm{R} \& \mathrm{D}$.

b) Pharmaceutical price regulation has immediately distributional effects for the consumers: citizens profit from lower prices. What would otherwise be profits for the pharmaceutical industry can - by regulating prices - be consumed by the citizens themselves or be invested funding in other types of health care. But to the degree that lower prices for innovative medicines lead also to lower levels of innovation, citizens loose the benefits of pharmaceutical innovations, e.g. gained life years or quality of life. Further, the access of citizens to a new product may be delayed because the pharmaceutical enterprises abstains from entering a market. Pharmaceutical enterprises also take into account potential parallel trade originating from a country when deciding on market entry, avoiding entry when parallel trade is likely to occur (see Ganslandt \& Maskus 2004, 1036 and in particular the study by Danzon et al. 2005).

c) Governments are deprived by parallel trade of an instrument of industrial policy. Under parallel trade those governments which explicitly want the pharmaceutical industry to receive a certain remuneration for their innovative effort and therefore grant higher prices cannot ensure that the patent holder actually receives the price they are willing to pay and in fact, are often paying (Towse 1998). Since the major share of the price difference can be appropriated as profit by the distribution chain and the parallel traders ${ }^{3}$, member states have, since they save only little from it, no strong substantive interest in parallel trade. Contrary to the Commission, they also have no institutional interest in the existence of this type of free trade per se.

Summarizing, the evaluation of parallel trade from a welfare point of view is ambiguous. Because it is based on regulatory differences, not on productivity, it has no effect on productivity. Moreover, for in-patent medicines, there is only one producer, who is granted a monopoly in exchange for its innovative effort. This situation makes it difficult to say, what a productivity gain should look like. There are negative implications, such as limited access to new medicines, even where the enterprise would enter the market were it not for the fear of parallel trade. The country or the health system of the country, may be willing to pay a price which is per se acceptable for the enterprise (e.g. because it is above production costs and thus contribution to recovering the costs of innovation), but the effects on prices elsewhere prohibit entry (cf. Maskus 2001 and Jelovac \& Bordoy 2005). Faced with these problems, the overall evaluation of parallel trade hinges on what is done with the price differences. It's evaluation by the Commission however, depended - nolens volens - on the formal criterion that it is an expression of the single market principle.

\footnotetext{
${ }^{3}$ The profit is up to $25 \%$ of the pharmacy price, hinting at low competition among parallel traders (Darbà \& Rovira 1998, 134, OECD 2001, 53 and Commission 1998, 4 on the distribution of profit margins)
}

The most obvious strategy for the pharmaceutical industry as the actor with the highest stakes and the clearest (viz. financial) interests would consist of lobbying for higher prices at the national level: in particular in those member states, where prices are lowest, to obtain higher profits, but also in order to remove the economic basis of parallel trade. Obtaining a higher price in a low-price country not only increases the profit made in this market, but the profit made in other markets too. But this national level strategy is not feasible, for the reason that the pharmaceutical industry has least influence there. The research-oriented pharmaceutical industry, which is most concerned by parallel trade, is concentrated in some countries, such as the UK, Germany or France. Here, it has the leverage of being both an important taxpayer and employer. This leverage is absent in countries where they are neither paying taxes nor employ many people and create economic value. In bilateral, national level bargaining situations, the industry has least leverage where it would need most (cf. Fisher Ellison \& Wolfram 2001).

Stimulated by the substantial forgone profits and the problem of having no leverage with "relevant" national governments, the pharmaceutical industry approached the problem of parallel trade using several counter-strategies. An early legal strategy aimed at creating legal obstacles for parallel trade, but was refuted by the ECJ ${ }^{4}$. The most basic strategy is the enterprise's decision to accept the price offered by a government or not: it may launch a new drug in a market immediately, later or not at all. In deciding, the enterprise will take into account the profit achievable in the market, defined by price and potential quantity. It will not enter, if the price achievable does not contribute to recovering the costs of R\&D. But it will also not enter, if the expected parallel trade originating from this market will diminish its profit elsewhere. As a consequence, enterprises delay or even abstain from entering a market if they expect parallel imports to originate from this market (see Danzon et al. 2005 and Lanjouw 2005). A further strategy relies on increasing the costs to parallel traders, by giving the same product various dosages, appearances and names in various national markets (Forrester 2000 and Isaac 2000). A new antiparallel-trade-strategy consists of limiting the supply of the product to wholesalers in a country from which parallel trade originates.

\section{TACKLING THE PROBLEM: EUROPEAN LEVEL NEGOTIATIONS ON THE SINGLE PHARMACEU- TICAL MARKET}

Apart from the unilateral national level strategies mentioned above, the pharmaceutical industry used also the European level. The issue of a single pharmaceutical market, national price regulation and parallel trade was treated at European level for many years now. Despite fluctuation in themes and participants, both, the set of core participants and the core issues treated, constitute a continuous negotiation system. The negotiations started in the 1980s, going through phases of informal meetings, like the Trianon Forum, but also phases, which were much more visible, like the Round Tables in the late 90s. The 'Group of 10' (G10) meetings initiated by the DG Enterprise in 2001 were another step in

\footnotetext{
${ }^{4}$ See the judgments Bristol-Myers Squibb vs. Paranova A/S (C-427/93), as well as C429/93 and C-436/ 93; see for the current legal situation Forrester (2000).
} 
which the issues unequal integration, regulated prices and its effect on the European pharmaceutical industry's competitiveness were discussed. The results remained vague at best (G10 Medicines (High level group on innovation and provision of medicines) (2002).

The following description is based on the available official documents, in particular the proceedings of the Round Tables, supplemented by coverage in related publications, e.g. the PPR (Pharma Pricing Review) (1997), PPR (Pharma Pricing Review) (1998), PPR (Pharma Pricing Review) (1999), and interviews with participants in the Round Tables, the Commission and the pharmaceutical industry conducted in the period 2000 to 2001.

\section{Negotiation Process}

The negotiations were initiated and driven by two proactive actors, the research oriented pharmaceutical industry organized in the European Federation of Pharmaceutical Industries' Associations (EFPIA) and the Commission. Both shared an interest in treating the issue, but as it turned out, differed with regard to what solution they favored.

The major driver was the industry which suffered from financial losses as described above. The issue of parallel trade can by its very nature not be solved by bilateral negotiations: the cause of the industry's problems are precisely those countries, where it has least influence on price setting and has to accept low price levels. Most often, these are governments of countries, in which the research oriented pharmaceutical industry is not present at all, and thus cannot threaten with relocation. Hence, a multilateral approach was required aiming at reaching low-price-countries indirectly, via the European level. To use the European level, the industry needed an actor willing to act as an agenda setter and to convene a European level negotiation round.

At the European level, the Directorate General III (DG III) was - despite no positive legal basis for action - nevertheless ready to engage on behalf of the industry: first, as the DG in charge of implementing the single market program, the issue of creating a single market in the pharmaceutical sector was a legitimate theme if treated under an industrial policy perspective. Second, DG III was interested in strengthening the European industry vis-à-vis the US and Japan (Commission (1994); COM(93)718). Quick access to a large market like a European single market together with a satisfying price level would be a good instrument to do so. Third, the Commission, usually interested expanding the EU's competence into new domains, had an institutional interest to get the issue on the European level and thus to get at least a role in the policy field (Schmidt 1998 and Pollack 2002).

As for the member states, three reasons can explain why they entered such negotiations at all: first, it was a low profile negotiation in a very informal setting. There was neither a danger of a dynamic that could get out of control nor the costs of a public failure if the negotiation failed. Second, given the ECJ's judgments in the cases of free trade in medical services ${ }^{5}$, government's feared that a solution by the ECJ

\footnotetext{
${ }^{5}$ In particular the judgements to Kohll and Decker C-258/96 and C-120/95, caused substantial debate.
}

could be worse for everybody than a negotiated, political solution. Third, as stated above, a price granted by a government is a political decision. Some governments, like the UK or Ireland, deliberately allow for higher prices for reasons of industrial policy. They are interested in securing an appropriate remuneration for innovative efforts, at home, but also throughout Europe. Parallel trade was seen skeptical by some actors, including the Commission, as merely extracting profits without any productive contribution; see also the statements cited below.

The first clearly identifiable step in the negotiation system is the process leading to the transparency directive; 89/105/EEC. While having no substantive impact, the directive reached its latent aim of establishing price regulation as a theme at the European level. Several attempts followed, both formal and informal often interrupted and restarted (see Shechter 1998). The Round Tables were the up to then most visible phase of the process. Moreover, it was the situation in which the positions held by the actors were articulated most clearly. For the DG in charge of industry, Commissioner Bangemann stated:

'Strict domestic price controls must be abolished. They are: a disadvantage from the point of view of industrial policy, as they lead to market distortions and make any sort of competition impossible; a disadvantage for the cost centres, since overall costs are not moderated on the grounds of increased volumes; a disadvantage for the single market. If prices throughout Europe were to drop to the lowest level to be found in any domestic European market, there would soon be no more pharmaceutical industry (...). If we were dependent on imports from third countries, the position of governments in relation to the pharmaceutical industry would certainly not be stronger.' (Round Table I 1996, 6/7)

For the member states Michael Noonan, Irish Minister for health, began by emphasizing the importance of the industry as an economic factor and the necessity, that it obtained the financial means necessary to remain engaged in $R \& D$. He then continued stating:

' (...) that unrestricted free movement is not compatible with unrestricted Government intervention in the domestic market. One or the other must give ground. Having said that, Member States cannot give ground on their prerogative to set health policy within their own jurisdiction. Nor is it acceptable that one country can or should impose its choice of health policy on its neighbours by the action of parallel trade. This would seem to point to the need for both the Commission and the Member States to show flexibility in the application of free movement where national price controls apply. ' (Round Table I 1996, 11)

The pharmaceutical industry, despite diplomatic selfrestraint, came to the Round Table with the aim either to abolish national price regulation or to stop parallel imports. The basic position is also visible from the proposals it forwarded: 'block exemption', i.e. the exclusion of medicines from the free trade. Or, a 'contractual approach' in which the industry would sell the medicine directly to the government or the health institution, cutting out potential parallel traders (Round Table I 1996, p. 47). 


\section{Negotiation Analysis}

The negotiation analysis will to cover a) the decision making mode, b) the issues involved and c) the positions of the actors on these issues.

a) Given the exemption of organizational aspects of health policy from Europeanization, see Art. 152 EC Treaty, any agreement would have required either a change of treaties or some kind of agreement outside of the treaties. The negotiation situation is no tâtonnement-process, in which all sides approach each other in a process of offers and counter-offers which converge over time. Further, the Commission had no agenda setting power to start a formal policy process comparable to EU policy making in other sectors. Nor did it have an agenda setting monopoly, by which it could keep issues and solution off the agenda. In this situation, the decision mode was such that any solution would have required the unanimous consensus of all member states. This asymmetric distribution of power, which rested exclusively with the member states, caused a negotiation process which can best be described as veto-bargaining: the proactive side, i.e. industry and Commission, developed proposals and options, aiming at finding support for it by drawing attention to the consequences of a continuation of the status quo, in particular for the European pharmaceutical industry. The reactive side, i.e. the member states, waited and decided whether they would follow any of these.

b) Regarding the issues at stake, the co-existence of national price regulation and parallel trade, the negotiation encompass a substantive issue - what price shall a pharmaceutical enterprise receive? - and two institutional issues: first, shall medicines be tradable or exempted from free trade? Second, shall pricing be transferred to the European level, by being harmonized or even centralized, equivalent to the market authorization?

While the Commission didn't hold a monopoly on formulating options, it assumed this role, and focused the discussions on some options, while excluding other possible solutions. After two Round Tables meetings, the Commission's communication of November $25^{\text {th }}, 1998$ was the first official statement of options as a basis for steps to come (Kommission/Commission (1998), 10/11). The options outlined were:

\section{Status quo - which would mean no changes;}

Full integration - creation and enforcing of price convergence in the EU either by a centralized price setting procedure by an agency or by 'co-operation' by the member states, which implies some form of collective decision by them;

A "Middle Way" - consisting of possible regulatory mechanisms, most of them already in use. The middle way option contained nothing a government could not already do unilaterally. So despite the label, the middle way option was in every respect equal to the status quo.

The options as outlined by the Commission were hence either a continuation of the status quo or some form of change towards more integration of price setting. The option raised for instance by Noonan, to handle the application of the free movement of goods principle more "flexible", were not mentioned. c) What are the preferences of the actors on the issues? Based on the description of the problem in the section on parallel trade above, most of the preferences on the issues can be derived straightforward.

Regarding the issue of price levels, the Commission is not concerned with the price level, because it is not involved in financing. However, the DG III in charge of industrial policy and hence to some degree the Commission as a whole, were in favor of strengthening the pharmaceutical industry, which can be achieved by granting higher prices. The issue was treated as industrial policy, and the fact that there should be a strong European pharmaceutical industry was always an explicit theme. The pharmaceutical industry's preference is straightforward: as a for-profit actor, it wants higher profits. Thus it would favor changes leading to higher prices, like abolishing national price controls. Or at least to changes which reduce the loss arising in other countries because of parallel trade originating form low-price countries such as southern member states. As for the member states, the ideal points in the price issue - the position about what is an appropriate price - differ substantially. As argued in the section on national price setting above, the price level granted by a government is its revealed willingness to pay. Given that there are no external restrictions, the price level reflects only an internal weighting of societal interests, in particular with regard to expenditure and access to new drugs. Looking only at the price levels, any government can be assumed to be indifferent towards an European price which is identical to the national price level. The preferences can proxied by the price level for pharmaceuticals at the manufacturer level (cf. Schneider et al. (1999) for data on price levels). The national price levels were heterogeneous in the phase of the Round Tables and the G10, and became even more heterogeneous since, due to the accession of new member states with even lower price levels.

With regard to the institutional questions, one option is moving forward towards to more integration, for which two scenarios were discussed in the Round Tables phase: Either abolishing national price regulation altogether or by centralizing price setting, e.g. by an European agency. The other option is to go backward, by de-integrating and abolishing parallel trade for pharmaceuticals. This "block-exemption approach" would imply that pharmaceuticals can no longer be traded between member states. The preferences of the actors in these issues are highly divergent: The Commission's concerns are purely institutional, i.e. it favors or rejects certain institutional solutions per se, independent of the outcome. Given its role as the 'motor of integration', active de-integration, the removal of established free trade in a sector, is no option. While the Commission had no formal agenda setting power comparable to the established EU policy making process, it nevertheless assumed this role and when formulating options explicitly left out the block exemption scenario.

From the point of the pharmaceutical industry, institutional issues and solutions are evaluated with regard to the expected outcome only, i.e. in terms of the prices and profits achievable. The abolishment of national price regulations would diminish both types of losses mentioned in the section on parallel trade: the direct losses due to price regulation and the indirect losses due to parallel trade as a consequence of 
different prices. A de-integration would keep price regulations in place but would remove parallel trade and the losses arising from it. Both options would hence be favored by the industry over the status quo, see the industry's position in Round Tables I (1996: p. 47).

For the member states, the financial implications of changes are as relevant as the institutional issue. Unsurprisingly several member states articulated the view that a renouncement of national control over prices would lead to higher prices, endangering the access of citizens to the medicines. But there is also a fundamental opposition towards any integration, harmonization or delegation of organizational issues in health care provision to the EU level. There is a very strong - stated and revealed - institutional preference that health policy must remain a national competence, affected neither by policy decisions of other member states nor by the Commission (van der Mei \& Waddington 1998). Member states are per se in favor of an institutional design, which does not involve any integration of health policy in the sense of a shift of competencies to the European level. In a situation of incompatibility among price regulation and free trade, at least some member states stated a preference for the de-integration option, see for instance the statement by Noonan cited above.

\section{The Deadlock}

Given the derived preferences and the options the deadlock is obvious. The focus of this step will be put on the member states, as the decisive actors. The problem arising from parallel trade can be tackled by addressing its economic or the legal-institutional foundations. There are institutional preferences, but there are also the financial implications of institutional changes to consider.

Regarding the legal-institutional foundations of parallel trade one scenario is a further integration. Member states are per se against a shift of competencies in health policy to the European level. This precludes a shift of the competence for price setting to the European level, independent of the actual price level resulting.

But there are also fundamental motives prohibiting any movement towards a harmonization of prices or even a "Single European Price". Both are equivalent, whereby a harmonization would imply roughly equivalent prices in all member states. Introducing a Single European Price, i.e. a uniform price for a medicine set for all member states, could be done by a European agency (the EMEA would suggest itself), but does not necessarily require this. Member states do not have to delegate the pricing decision towards an independent European agency. Instead, they could use an intergovernmental decision making mode, parallel to the EU policy processes. However, a consensus to introduce such a institutional change is not to be expected: Assume that the member states agree to set a Single European Price by simple majority. The resulting price would be the median price. While the median price has presumably decreased due to the access of Eastern European countries with lower price levels, there is still no reason why a member state with a price level below the median price should accept an institutional change forcing it to pay the median price. Nor is there a reason why a member state granting for reasons of industrial policy a high price should accept to cut its subsidy by agreeing on a lower price. There is no evidence of a universal wish to average down pharmaceutical prices: Governments currently granting high prices could also unilaterally use price regulations to contain costs, but do not. If the "Single European Price" has to be decided unanimously, the most likely result is a deadlock with consequences on the availability of the medicine. So even under an institutional design which does not delegate competence to an independent third party, some member states will oppose and veto the creation of such a price setting mode. The core of the dissent is the fact that each member state's government can unilaterally set the price which is the optimum given its mix of motives. No member state can do better than it already does, there are no improvements achievable by more integration.

The option of removing the legal or rather factual possibilities for parallel trade created less opposition. Indeed, the de-integration option would have been of advantage to the member states. If pharmaceuticals are exempted from free trade, member states would neither loose control nor incur higher costs for pharmaceuticals. Low-price-countries loose nothing in the de-integration scenario. But they might get quicker access in those cases, where a pharmaceutical enterprise currently hesitates the launch of a new product in their market fearing parallel trade. On the other hand, high-pricecountries want the industry and not the parallel trades to receive the price they are granting.

While there were feasible options, which would have been an improvement compared to the status quo, it was clear that the Commission would not propose these. The commitment to the acquis communautaire, shared by the Commission but also by the member states, excluded any open step towards a de-integration. Neither the issues, the preferences of the actors, nor the decision situation did change since then. On the contrary the situation became even more difficult as in the course of the EU enlargement the member states became more heterogeneous. The analysis of the current situation is thus equivalent to the situation in the Round Tables or the more recent G10 process (G10 Medicines 2002).

\section{FACTUAL DE-INTEGRATION BY THE ECJ}

Theories on the leeway of non-political actors, such as bureaucracies and courts, predict, that deadlock among political actors creates leeway for judiciary as an agent who can only be overruled by a consensus among all political actors (Tsebelis 2002, chap. 10 and 11). The farther the political actors are apart on the issues at hand, the larger the leeway for the court. The above sections showed that the negotiation processes can be explained quite well with reference to the preferences of the political actors, such as the member states and the commission. But the outcome reached now, is best explained by the theory proposed by Tsebelis.

In the present case, the leeway created by dissent among the political actors was used by the ECJ to make policy. The problem at hand has, as was outlined, two dimensions: the price level, as the substantive one, and the application of the single market principle, as the institutional one. While the ECJ did not take a stance on the question of a "Single European" price, it did take a stance in the institutional issue. Contrary to the situation in the question of free movements of patients, the legal basis was much more straightforward 
for pharmaceuticals. In the former, two contradicting principles were present in the treaty, viz. a strictly national competence for health care and the single market for services and products, also in the domain of health care. In the latter, the national regulation of prices as well as parallel trade were justified by the current legal setting in the treaties, but the implications for real life were much more substantial in terms of impact on the industry and the overall welfare.

The process of factual de-integration started with a unilateral strategy to avoid parallel trade implemented by the Bayer AG. From the early 90s on, the French and Spanish subsidiaries of Bayer limited their supply of Adalate, a medicine for treatment of cardiovascular diseases, to the wholesalers in these countries. According to the Commission, which investigated the case, Bayer had identified wholesalers which directly or indirectly exported Adalate to the UK by the serial numbers of packages. To counteract the parallel trade, Bayer limited the sale of Adalate to them, implementing a kind of quota system. The aim was basically to limit the supply of Adalate in these markets to what was actually consumed so that nothing could be exported in other countries, in particular to the UK. The figures in question were quite illustrative for the problem and the stakes. Adalate prices in France and Spain were about $40 \%$ below those in the UK, and the parallel trade led to a loss of profit in the magnitude of about 50 Mio. Euro (see judgment of the Court of First Instance, T-41/96, Nos. 1 to 4).

Wholesalers complained with the Commission, which in turn started a formal investigation against Bayer, leading to a decision in which Bayer was sentenced to stop these activities and to pay a substantial penalty; see Commission's decision 96/478/EG from January 1996. Bayer in turn sued the Commission at the Court of First Instance, demanding a repeal of the Commission's decision. This was granted in the Court of First Instance' judgment from October 2000; see judgment of T-41/96. In 2001, the European as well as the German Association of Pharmaceutical Importers, together with Sweden and the Commission sued in turn for a repeal of the repeal, i.e. of judgment T-41/96. In its judgments of 2004 in the cases C-2/01 and C-3/03, the ECJ confirmed the position taken by the Court of First Instance. Even if Bayer did engage in a unilateral policy to avoid parallel trade, this is legal and no limitation of trade in the sense of Article $85^{6}$, section 1. Contrary to the arguments of the Attorney General, whose opinion explicitly referred to the economic issues involved, the ECJ only referred to the legal aspects, not to the facts as such but to the Court of First Instance' evaluations of the facts.

In the core of the case was not so much whether Bayer's unilateral strategy of limiting the supply of Adalate to was legal, but whether doing so was done in agreement with the wholesalers and thus constituted a "concerted practices which may affect trade" in the sense of Article 85. The ECJ judged that it was no such "concerted practice", no agreement between Bayer and the wholesalers, but a unilateral strategy to counter parallel trade. This as such, is not illegal. In a later judgment in the case of SYFAIT et al. vs. GlaxoSmithKline, C-53/03, the situation was equivalent. The ECJ rejected treatment of the case for formal reasons.

\footnotetext{
${ }^{6}$ In the current consolidated Nice version of the EC treaty, this article is now article 81.
}

In the most recent judgment, Sot. Lelos kai Sia EE et al. vs. GlaxoSmithKline(C-468/06), from September $16^{\text {th }} 2008$, the Court reiterated its position, and allowed the limiting of drug sales to wholesalers.

With its judgments, the ECJ factually exempted medicines from free trade, setting a policy of de-integration, very much along the lines of the block-exemption approach. At the same time free trade stays in place formally, an issue of high symbolic value for the Commission and the member states alike. The ECJ remained in the leeway delineated by the positions of the actors, in that it set a solution which is most in line with the preferences of everybody: the member states neither have to renounce competencies nor have to accept a Single European Price. The Commission had to cut back on the parallel trade, which is something it is obliged to, but it obtained a solution which is better for the European industry. The industry got in the end, higher profits. The only actors having lost, are the parallel traders, who were seen by many as "free riding", earning windfall profits.

\section{SUMMARY AND CONCLUSIONS}

The incomplete integration of the European pharmaceutical market characterized by free trade combined with national price controls led to problems concerning the stakeholders in the European pharmaceutical market. In order to tackle the problems, a negotiation process was established which did not lead to a negotiated solution.

Looking at the institutional and material preferences of the member states, as the actors with the exclusive competence to set a policy, it becomes clear that any explicit political solution to the problem was obstructed: member states blocked a movement towards a more integrated pharmaceutical market with a centralized price setting or a harmonization of prices. For all of them, this would imply a renouncement of control over prices. Depending on the "European" price level established level this would for some member states imply that they are unable to support their industry by granting higher prices, while for some countries, a harmonized "European price" would imply higher prices and expenditure. While in agreement on the institutional issue of retaining national competence for health, the member states are divided on the substantive issue of what is an "appropriate" price.

On the other hand, the one-way character of European integration, embodied in the Commission and the acquis communautaire ideology, blocked a de-integration policy, i.e. the way back to nationally separated markets and an exemption of medicines from free trade. While setting such a policy was possible, it would have required a change of the treaties, and would have constituted an unprecedented step in a process of continuous albeit at times interrupted integration.

So a situation - seen as suboptimal by most actors - persisted: trade is free, but the foundations of it are not differences in productivity, but in regulation. The effects of parallel trade are seen as harmful to the overall welfare: drugs are not or with delay launched in some states for fear of parallel trade originating from that country. Even if the lower price granted by the country's regulators is acceptable to the pharmaceutical industry per se, patients are excluded from access. The potential savings from the parallel trade are not 
or not fully realized by the health systems but are appropriated as profit by the parallel traders, which are seen as "unproductive".

Faced with this deadlock, the pharmaceutical industry tried to tackle the problem using the unilateral strategy of limiting the supply to wholesalers and parallel traders, which brought the issue to attention of the Commission and the ECJ. The judicial option was the only way by which the only actor undoubtedly profiting from parallel trade - the parallel traders themselves - were able to obtain a role in the process. In the political process, parallel traders had the weakest position, because they were seen, also by the Commission, as profiting without creating value (Commission 1998).

By tolerating the anti-parallel trade strategy, the ECJ set a solution, which the political actors can accept, but were unable to create. This strong role of the ECJ is similar to the ECJ's role in creating a European market for health care (Martinsen (2005). It differs in that the ECJ ruled in favor of extending the single market principle in the latter case, while it decided in favor of factually limiting the principle in the case of pharmaceuticals.

Given these developments, one would not expect any more activity in this issue. The pharmaceutical industry obtained a feasible option to counteract parallel trade, viz. to limit sales in the countries and in particular to those wholesalers, from which parallel trade originates. The outcome is cost neutral for member states, allowing them to set prices at levels which reflect their national particularities and to subsidize their industry. A formal harmonization of price levels is not to be expected. What can be expected in the long run is a convergence of prices, caused by a convergence of the motives and constraints of the governments doing the pricing.

Regarding the implications for the general theme of lobbying and regulation in the EU, the case presented here is typical to the degree that the party mainly concerned, the pharmaceutical industry, turned to the EU level to obtain a solution which was not to be achieved at national level (cf. Grande 1996, Greenwood et al. 1994, Greenwood 1997 and Quittkat 2006 for similar cases and a discussion of this European level strategy). It is also typical in the sense, that the EU Commission was willing to take up the theme - despite no legal basis in the treaties - in order to establish the theme on the European level and to obtain a "foot in the door" (cf. Schmidt 1998 for more examples). Moreover, it is a case in point for the impact of strategic framing - the Commission treated the issue as industrial policy, where it was possible to derive a competence, not as health policy, which it basically is but where it was impossible to treat the theme at all (cf. in particular Shechter 1998 on the usage of issueframing in lobbying strategies). The member states treated the issue as health policy, thus precluding a role of the Commission. It is also typical for - and a confirmation - of Tsebelis' hypothesis on the role of the ECJ, in the sense that the ECJ has a role, when the political actors cannot agree on a political solution nor can agree on refuting the ECJ's decision. Both, a constructive solution - "Europeanizing" an aspect of health policy - and a refutation of what the ECJ decided would have required a formal exemption of pharmaceuticals from the single market by way of a change in a treaty.
But the case is also atypical, and something genuinely new, in that it is factual a de-integration, a step backwards. In other fields, such as cross border care, the ECJ substantially contributed to the extension of the single market in a sector, where no government wanted any integration whatsoever. But the solution set here is factually exempting a substantial market segment from the application of the free trade principle. The solution set is also "political" in that it refers to the welfare costs of the present situation and the right of the producers to protect their commercial interests (cf. ECJ judgment C 468/06, No. 76). It is difficult to make a statement about whether the solution set by the ECJ was anticipated by the industry or the states. The ECJ has in the past produced it share of surprising judgments in the domain of health care in general and pharmaceuticals in particular, fully justifying its label as a "powerhouse " of integration (Howe 2004). And indeed, one motivation underlying the Round Tables in the late $90 \mathrm{~s}$, was to come to a negotiated solution before the ECJ might set an arbitrary one. Looking at the solution set and the problem, it is however quite clear, that the ECJ did not impose a solution which is against the interests of the crucial actors. All of them can live with it. The solution set is likely to be stable, because there is no consensus to revoke it.

\section{REFERENCES}

Attridge, J. (2003). A single European market for pharmaceuticals: could less regulation and more negotiation be the answer? European Business Journal, 15, 122-134.

Berndt, E. R. (2002). Pharmaceuticals in U.S. health care: determinants of quantity and price. Journal of Economic Perspectives, 16, 45-66.

Burstall, M.L. (1990). 1992 and the pharmaceutical industry. London: The IEA Health and Welfare Unit.

Commission (1994). Outlines of an industrial policy for the pharmaceutical sector in the European Community (COM(93)718 of 2 March 1994. Brussels: Office for Official Publications of the European Communities.

Commission (1998). communication on the single market in pharmaceuticals; COM (98) 588 final. Brussels: Office for Official Publications of the European Communities.

Commission (2003). communication on parallel imports of proprietary medicinal products for which marketing authorisation have already been granted COM/2003/0839 final. Brussels: Office for Official Publications of the European Communities.

Danzon, P. M., \& Chao, L.-W. (2000). Cross-national price differences for pharmaceuticals: how large and why? Journal of Health Economics, 19, 159-195.

Danzon, P. M., \& Furukawa, M. F. (2003). Prices and availability of pharmaceuticals: evidence from nine countries. Health Affairs Web Exclusive W3-521 - W3-536.

Danzon, P. M.,Wang, Y. R., \& Wang, L. (2005). The impact of price regulation on the launch delay of new drugs- evidence from twenty-five major markets in the 1990s. Health Economics, 14, 269-292.

Darbá, J., \& Rovira, J. (1998). Parallel imports of pharmaceuticals in the European Union. Pharmacoeconomics, 14, 129-136.

Fisher Ellison, S., \& Wolfram, C. (2001). Pharmaceutical prices and political activity. Cambridge. NBER Working Paper 8482.

Forrester, I. S. (2000). The repackaging of trade marked pharmaceuticals in Europe. European Intellectual Property Review, 22, 512-519.

G10 Medicines (2002). Report by the High level group on innovation and provision of medicines. Brussels: Commission.

Garattini, S., \& Bertele, V. (2004). The role of the EMEA in regulating pharmaceutical products. In: Mossialos, E., Mrazek, M., \& Walley, T. (Eds.), Regulating pharmaceuticals in Europe: striving for efficiency, equity and quality. (pp. 80-96). Maidenhead: Open University Press.

Grande, E. (1996). The state and interest groups in a framework of multilevel decision-making: the case of the European Union. Journal of European Public Policy, 3, 318-338. 
Greenwood, J. (1997). Representing interests in the European Union. London: Macmillan.

Greenwood, J., Grote, J. R., \& Ronit, K. (Eds.) (1994). Organized interests in the European Community. London: Sage.

Hancher, L. (2004). The European Community dimension: coordinating divergence. In Mossialos, E., Mrazek, M. \& Walley, T. (Eds.), Regulating pharmaceuticals in Europe: striving for efficiency, equity and quality. (pp. 55-79) Maidenhead: Open University Press

Howe, M. (2004). The European Court: the forgotten powerhouse building the European superstate. Economic Affairs, 24, 17-21.

Isaac, B. (2000). Free movement of goods II: pharmaceuticals, trade marks and parallel imports. In Goldberg, R \& Lonbay, J. (Eds.), Pharmaceutical medicine, biotechnology and European law. (pp. 25-44). Cambridge: Cambridge University Press.

Jelovac, I., \& Bordoy, C. (2005). Pricing and welfare implications of parallel imports in the pharmaceutical industry. International Journal of Health Care Finance and Economics, 5, 5-21.

Kanavos, P. (2000). The single market for pharmaceuticals in the European Union in light of European Court of Justice rulings. Pharmacoeconomics, 18, 523-532.

Kon, S., \& Schaeffer, F. (1997). Parallel imports of pharmaceutical products: a new realism, or back to basics. European Competition Law Review, 18, 123-144.

Lanjouw, J. O. (2005). Patents, price controls, and access to new drugs: how policy affects global market entry. New York/Stanford: NBER Working Paper No. 11321.

Martinsen, D. S. (2005). Towards an internal health market with the European court. West European Politics, 28, 1035-1056.

Maskus, K. E. (2001). Parallel imports in pharmaceuticals: implications for competition and prices in developing countries. Geneva: World Intellectual Property Organization.

Mossialos, E., \& Palm, W. (2003). The European Court of Justice and the free movement of patients in the European Union. International Social Security Review, 56, 3-29.
OECD (2001). Competition and regulation issues in the pharmaceutical industry. Paris: OECD.

Permanand, G., \& Mossialos, E. (2005). Constitutional asymmetry and pharmaceutical policy-making in the European Union. Journal of European Public Policy, 12, 687-709.

Pollack, M. A. (2002). The engines of European integration: delegation, agency, and agenda setting in the EU. Oxford: Oxford University Press.

PPR (Pharma Pricing Review) (1997). Bangemann Round Tables: no break in EU pricing impasse. Pharma Pricing Review, 2, 1-7.

PPR (Pharma Pricing Review) (1998). Frankfurt II: all smiles but no solutions. Pharma Pricing Review, 3, 4-6.

PPR (Pharma Pricing Review) (1999). Bangemann process: the end of the road? Pharma Pricing Review, 4, 1-4.

Quittkat, C. (2006). Europäisierung der Interessenvermittlung. Wiesbaden: VS Verlag.

Round Table I (1996). Round Table "Completing the Single Pharmaceutical Market". Brussels: EFPIA/IMS Health .

Schmidt, S. K. (1998). Commission activism: subsuming telecommunications and electricity under European competition law. Journal of European Public Policy, 5, 169-184.

Schneider, M. Hofmann, U., Biene-Dietrich, P., Späth, B., \& Mill, D. (1999). Die deutschen Arzneimittelpreise im europäischen Vergleich. Augsburg: BASYS.

Shechter, Y. (1998). Interests, strategies, and institutions: lobbying in the pharmaceutical industry of the European Union. London: London School of Economics and Political Science.

Towse, A. (1998). The pros and cons of a single 'Euro-price' for drugs. Pharmacoeconomics, 13, 271-276.

Tsebelis, G. (2002). Veto players: how political institutions work. Princeton: Princeton University Press.

Van der Mei, A. P., \& Waddington, L. (1998). Public health and the treaty of Amsterdam. European Journal of Health Law, 5, 129-154.

(C) Peter Kotzian.; Licensee Bentham Open.

This is an open access article licensed under the terms of the Creative Commons Attribution Non-Commercial License (http://creativecommons.org/licenses/by-nc/3.0/) which permits unrestricted, non-commercial use, distribution and reproduction in any medium, provided the work is properly cited. 